\title{
Indexing Tools for Indian Citrus Ringspot Virus (ICRSV)
}

\author{
Sanjeev Sharma*, ${ }^{*}$ Balwinder Singh ${ }^{2}$, Avinash Nagpal ${ }^{3}$, G. S. Virk ${ }^{3}$ and A. A. Zaidi ${ }^{4}$ \\ ${ }^{1}$ Lyallpur Khalsa College, Jalandhar-144001, India \\ ${ }^{2}$ Khalsa College, Amritsar-143001, India \\ ${ }^{3}$ Department of Botanical and Environmental Sciences, Guru Nanak Dev University, Amritsar 143005, India \\ ${ }^{4}$ Molecular Plant Virology Laboratory, Institute of Himalayan Bioresource Technology, Council of Scientific and Indus- \\ trial Research, Palampur 176061 (H.P.), India
}

\begin{abstract}
Indian citrus ringspot virus (ICRSV) is known to cause serious disease problem in Kinnow (Citrus nobilis Lour $\times$ C. deliciosa Tenora). This paper reports the various methods viz. Bioassay, ELISA and RT-PCR for indexing of ICRSV. Bioassay was performed on Chenopodium amaranticolor, Cucumis sativus, Nicotiana glutinosa, N. tabacum, Petunia hybrida and Phaseolus vulgaris. However necrotic local lesions were observed only in case of Chenopodium amaranticolor and Phaseolus vulgaris. Infected trees were also found positive by indirect ELISA. RT-PCR of the infected plants showed an amplification of 539 bp fragment corresponding to coat protein gene and gene for nucleic acid binding protein.
\end{abstract}

Keywords: Kinnow, ICRSV, Bioassay, ELISA, RT-PCR.

\section{INTRODUCTION}

Mandarins, loose skinned citrus fruits, constitute a commercially important group of fruit trees. Kinnow mandarin, a hybrid between King and Willow mandarins (Citrus nobilis Lour x $C$. deliciosa Tenora) is one of the most important fruit crops and its cultivation is considered to be a highly paying proposition in India. In recent years, tremendous loss in yield and quality of this fruit crop has been observed due to various fungal, viral and bacterial diseases. A number of viruses are known to infect Kinnow trees and their consequences range from latent infection with little apparent effect on the host to its death. Among different viruses known to infect Kinnow, Indian citrus ringspot virus (ICRSV) is widely distributed throughout the country limiting the production of quality fruits [1-5]. The disease was first described by Wallace and Drake (1968) from California and has since been reported from many areas worldwide [6]. The leaves of infected plants exhibit typical chlorotic rings of variable diameter and drop prematurely. Several affected trees show dieback and decline type of symptoms and thus become less productive. A decrease in fruit weight, number, size and juice content of infected trees has also been observed $[2,4,7]$. During a survey recently conducted by us in major Kinnow growing zones of Northern states of India, the percent incidence of the disease ranged from 66 to $91.33 \%$ [8].

*Address correspondence to this author at the Department of Botany, Lyallpur Khalsa College, Jalandhar-144001, India;

E-mail: sanbot@rediffmail.com
Accurate information on the tools for indexing of virusinfected trees is highly important for decisions to implement a virus eradication or suppression programme. The literature on ICRSV identification had been noticeably confusing over the years. The disease was earlier described as a "graft transmissible disorder" of citrus in California by Wallace and Drake in 1968 and they assigned it the name "citrus ringspot" [6]. The infected plants showed symptoms of chlorotic flecking of young leaves and yellow blotches and rings on mature leaves. In most cases, the infected trees showed bark scaling symptoms of psorosis disease. Timmer and Benatena (1977) suggested that Citrus ringspot virus (CRSV) was related to Citrus psorosis virus (CPsV) and caused bark scaling in the infected plants [9]. A number of studies have suggested that ringspot and psorosis are variants of the same disease [10-12]. Until the year 2000, the name Citrus ringspot virus had been used for two quite different viruses. One of them is Citrus psorosis virus belonging to genus Ophiovirus [13-15] and the other is Indian citrus ringspot virus (ICRSV) [16, 17]. However, Rustici et al. [17] while studying an isolate of ICRSV from kinnow mandarin in India demonstrated that purified virus yielded a major band of $34 \mathrm{kDa}$ and a ssRNA of about $7.5 \mathrm{~Kb}$, which was infectious [16]. Keeping in view very little and confusing information available about indexing of ICRSV, the present study was planned to standardize methods for its indexing viz. Bioassay, ELISA and RT-PCR.

\section{MATERIALS AND METHODS}

\section{Bioassay}

Extracts were prepared from young symptomatic leaves of kinnow plants. Infected leaves were detached from the tree, washed with tap water followed by double-distilled 
water to remove any extraneous matter. The leaves were dried and ground more or less homogenous in $0.1 \mathrm{M}$ phosphate buffer at $\mathrm{pH}$ 7.0. The homogenate was squeezed through two layers of muslin cloth and the filtrate was used as a standard extract and applied to the leaves of test plants viz. Chenopodium amaranticolor, Cucumis sativus, Nicotiana glutinosa, N. tabacum, Petunia hybrida and Phaseolus vulgaris after abrasing the leaves with corborandum powder with the help of forefinger stroking from petiole to tip of the leaf whist supporting the leaf with other hand. Immediately after inoculations, the leaves were washed with distilled water to remove excess inoculum and corborandum powder and were labeled. Observations on appearance of visual symptoms on the test plants were recorded daily.

\section{Indirect ELISA}

Symptomatic leaves from infected kinnow plants were tested for the presence/absence of ICRSV employing indirect ELISA. Leaf samples were triturated in extraction buffer $(1: 10 \mathrm{w} / \mathrm{v})$. Antibodies, positive and negative controls were procured form Dr. Y.S Ahlawat, Indian Agriculture research institute (IARI), New Delhi (India). Enzyme conjugate and substrate were procured from Bangalore Genei Pvt. Ltd. (India). The procedure adopted for ELISA was as described By Clark and Adams [18]. The absorbance at $405 \mathrm{~nm}$ was measured with flow ELISA microplate reader. The reaction was considered positive only if the mean absorbance value was more than three times of negative control.

\section{RT-PCR}

Symptomatic leaves $(100 \mathrm{mg})$ of kinnow plants were used for total RNA extraction by Tri-reagent (Sigma, USA) according to manufacturer's instruction. Specific primers for ICRSV (Upstream (U): 5' CCAACTGGATGAAAT 3', Downstream (D): 5' GAGCCAAGCGTTCAGA 3') were designed by aligning the sequences available in the EMBL Database to amplify partial coat protein gene and gene for nucleic acid binding protein and were got synthesized from Bangalore Genei Pvt. Ltd. (India).

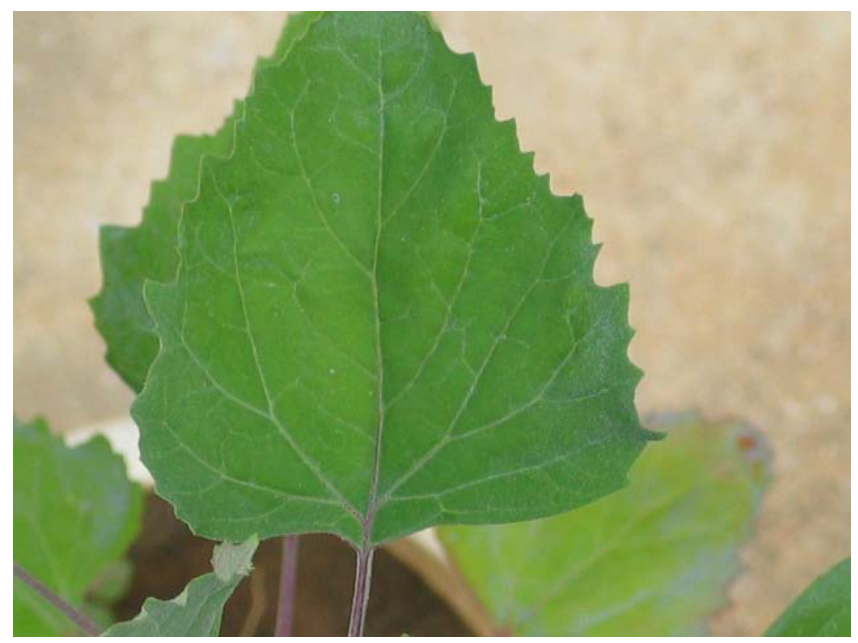

(a)
Reverse transcription was performed in $0.2 \mathrm{ml}$ thin walled tubes using the total RNA as the template. The reaction was carried out in a total reaction volume of $50 \mu 1$ at $37^{\circ} \mathrm{C}$ for $1.15 \mathrm{~h}$ with $5 \mathrm{x}$ reverse transcriptase buffer (Promega, USA), $10 \mathrm{mM}$ each dNTP, $200 \mathrm{ng}$ down stream (D) primer, 25 units of RNase inhibitor and $200 \mathrm{U}$ of M-MLV reverse transcriptase (Promega, USA). This was followed by incubation at $70^{\circ} \mathrm{C}$ for $5 \mathrm{~min}$ and the reaction mixture was transferred to ice immediately.

PCR was carried out in thermocycler (Gene Amp PCR system 9700, Applied Biosystems, Singapore) with $50 \mu \mathrm{l}$ of total reaction mixture containing $3 \mu \mathrm{l}$ cDNA, $1 \mu \mathrm{l}(0.2 \mu \mathrm{g})$ of upstream primer (U), $1 \mu \mathrm{l}(0.2 \mu \mathrm{g})$ of downstream primer (D), $5 \mu 1$ of 10xTaq Polymerase buffer (Genei, Bangalore, India). The reaction mixture was heated to $94^{\circ} \mathrm{C}$ for $1 \mathrm{~min}$, annealing at $52{ }^{\circ} \mathrm{C}$ for $1 \mathrm{~min}$ and elongation at $72{ }^{\circ} \mathrm{C}$ for 5 min were performed. PCR product was run on $1 \%$ agarose gel at $80 \mathrm{~V}$, stained in ethidium bromide $(0.5 \mathrm{mg} / \mathrm{ml})$ and visualized with UV transilluminator.

\section{RESULTS AND DISCUSSION}

\section{Bioassay}

Local necrotic lesions were observed only in leaves of Chenopodium amaranticolor and Phaseolus vulgaris. These lesions developed in about 10-12 days of inoculation. However, such symptoms were not observed in other host species tested viz. Cucumis sativus, Nicotiana glutinosa, Nicotiana tabacum and Petunia hybrida.

Bioassay is probably the most widely used approach for virus indexing because specialized skills are not required to perform the test. The technique involves the use of indicator plants whose leaves react by developing highly visible necrotic spots, when treated with an extract of a virus-infected plant [19]. In the present investigation, bioassay was performed using Chenopodium amaranticolor, Cucumis sativus, Nicotiana glutinosa, N. tabacum, Petunia hybrida and Phaseolus vulgaris as indicator host species for detection of

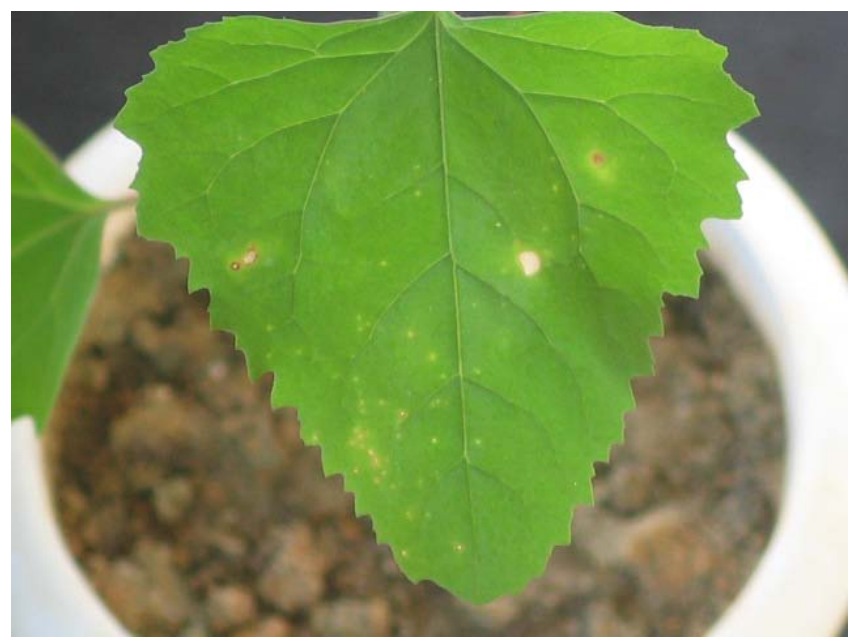

(b)

Fig. (1). Necrotic local lesions observed in Chenopodium amaraticolor when inoculated with extracts of symptomatic leaves of Kinnow plants (a) Control (b) Infected leaf. 


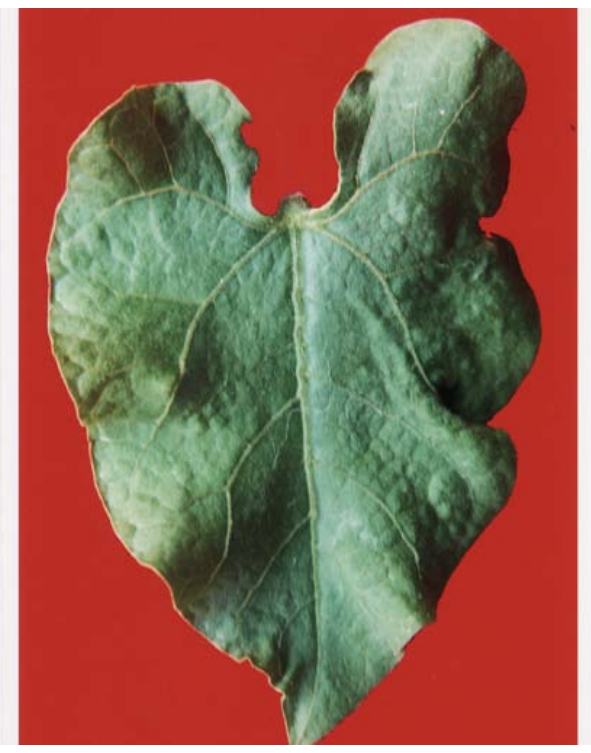

(a)

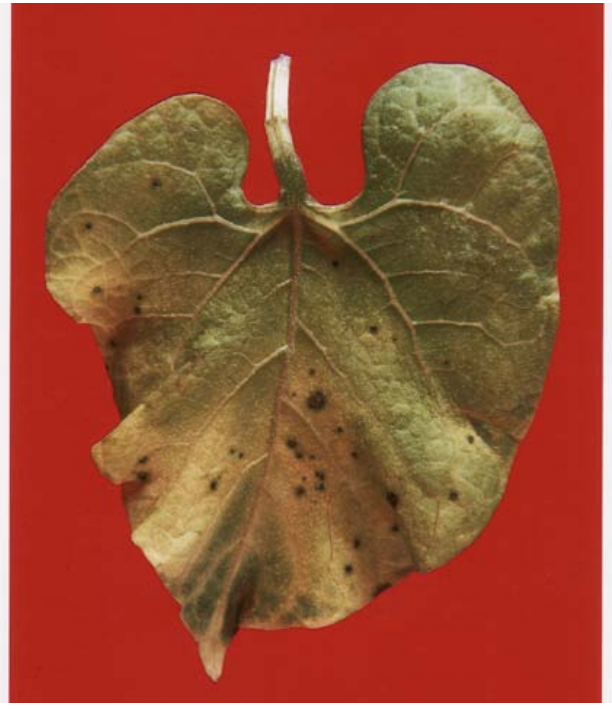

(b)

Fig. (2). Necrotic local lesions observed in Phaseolus vulgaris when inoculated with extracts of symptomatic leaves of Kinnow plants (a) Control (b) Infected leaf.

ICRSV. Local necrotic lesions were observed only in leaves of $C$. amaranticolor and P. vulgaris (Figs. 1 and 2). However earlier studies reported that ICRSV could not be transmitted by mechanical inoculations on herbaceous hosts and by some citrus cultivars $[2,20]$.

\section{Indirect ELISA}

The absorbance at $405 \mathrm{~nm}$ was measured with flow ELISA microplate reader. The reaction was considered positive only if the mean absorbance value was more than three times of negative control. The mean absorbance values at $405 \mathrm{~nm}$ for negative and positive controls were 0.021 and 0.401 , respectively. The absorbance values for all the plants used for this analysis ranged between $0.346-0.433$, indicating ICRSV infection of these plants (Data not shown).

Among the various possible ways to detect plant viruses, serological techniques are frequently favoured because of their specificity, speed and the scope they provide for standardization. The technique utilizes the ability of antibodies raised in animals to recognize proteins, usually the coat protein, of the virus of interest [21]. Among the various forms of ELISA, available for the detection of plant viruses viz. double antibody sandwich ELISA (DAS-ELISA), triple antibody sandwich ELISA (TAS-ELISA) and indirect ELISA, indirect ELISA is one of the reliable and cost effective methods used for detection of a large number of plant viruses like Andean potato latent virus (APLV) [22], Apple stem grooving virus (ASGV) [23], Florida hibiscus virus (FHV) [24], Pepper yellow mosaic virus (PYMV) [25], Plum pox virus (PPV) [26]. In the present study also, indirect ELISA was used successfully as a tool for ICRSV indexing.

\section{RT-PCR}

\section{RNA Isolation}

The isolated RNAs from infected samples were run on $1 \%$ agarose gel to confirm presence/absence of viral RNA
(Fig. 3). A band corresponding to $7.5 \mathrm{~Kb}$ fragment typical of ICRSV RNA was observed in lane 1, in which RNA from an infected plant was loaded. Such band was not observed in lanes 2 and 3 where RNAs from healthy plants were loaded (Fig. 3). In an earlier study, Rustici et al. [16], reported ICRSV to possess a ssRNA genome of 7500 nucleotides and a capsid protein $(\mathrm{CP})$ of $34 \mathrm{kDa}$.

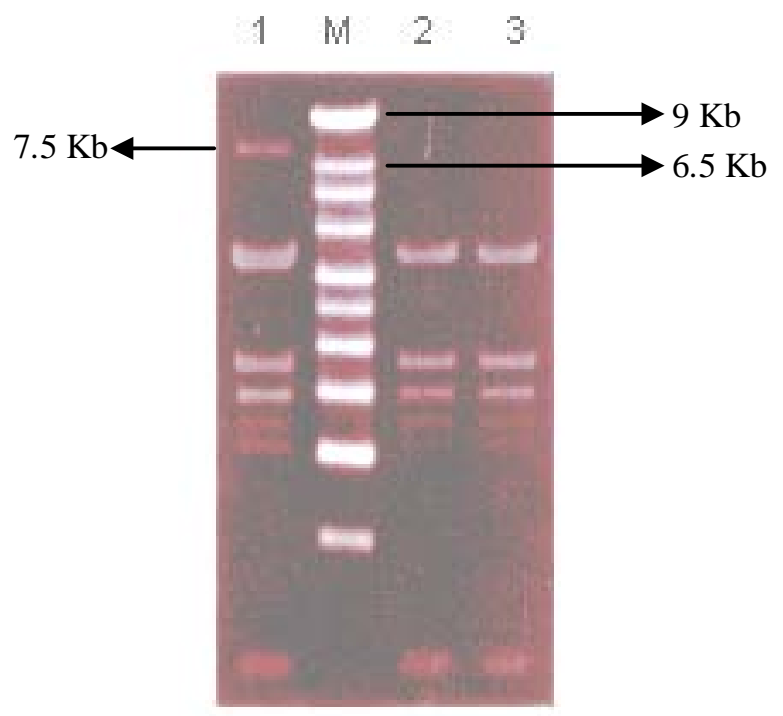

Fig. (3). Agarose gel electrophoresis of RNAs isolated from healthy and virus infected plants. (Lane M-Mellinium marker; Lane 1-RNA from ICRSV infected plant showing 7.5 Kb fragment of viral RNA; Lanes 2 and 3-RNAs from healthy plants).

\section{RT-PCR}

RT-PCR analysis of kinnow plants tested positive for ICRSV by bioassay and indirect ELISA has shown an amplification of $539 \mathrm{bp}$ fragment corresponding to partial coat protein gene and gene for nucleic acid binding protein (Fig. 
4). As ELISA lacks the sensitivity required for the detection of plant viruses, which occur in very low concentrations in infected tissues, many workers have used RT-PCR for indexing of different viruses to overcome this problem [27-34]. The procedure is extremely sensitive, fairly inexpensive and requires minimal skills to perform [35].

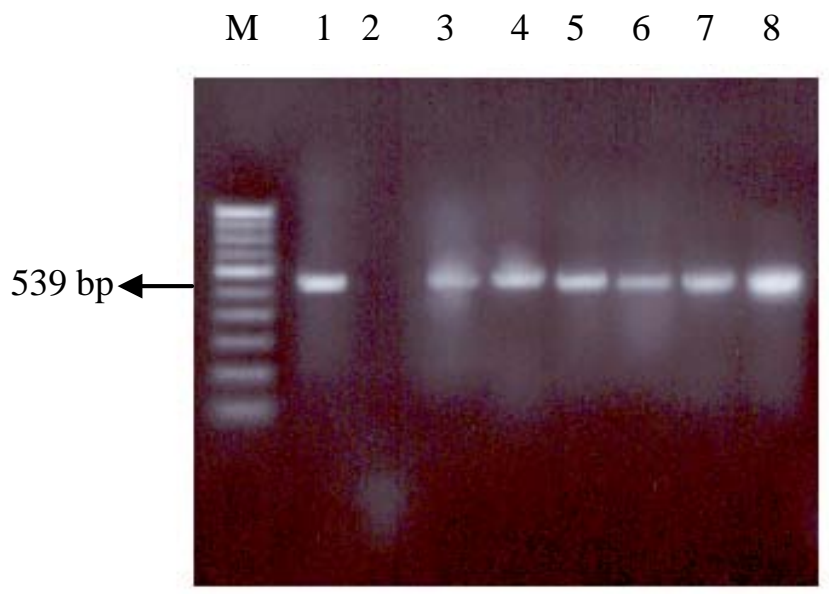

Fig. (4). Agarose gel electrophoresis of RT-PCR products of ICRSV infected kinnow plants. Lane M - 100 bp DNA ladder, Lanes 1 and 2 - Positive and Negative controls respectively, Lane 3 - 8 infected kinnow plants.

\section{CONCLUSION}

Indian citrus ringspot virus (ICRSV) is known to cause serious disease problem in Kinnow. As kinnow is propagated vegetatively, the use of infected budwood results in widespread occurrence of ICRSV. Accurate information on the tools for indexing of virus-infected trees is highly important for decisions to implement a virus eradication or suppression programme. In the present study, methods have been standardized for indexing of ICRSV viz. bioassay, ELISA and RT-PCR. The protocols developed for ICRSV indexing in the present investigation seems to be much effective as large number of the plants can be indexed in relatively lower costs and less time.

\section{ACKNOWLEDGEMENT}

The authors are thankful to the University grants commission (UGC), New Delhi, India, for providing the financial assistance.

\section{REFERENCES}

[1] Byadgi AS, Ahlawat YS, Chakraborty NK, Verma A, Srivastava H, Milne RG. Characterstics of a filamentous virus associated with citrus ringspot in India. Proc $12^{\text {th }}$ Conf Intern Org. Citrus Virol Riverside USA 1993; pp. 155-62.

[2] Byadgi AS, Ahlawat YS. A new viral ringspot disease of citrus (Citrus species) in India. Indian J Agric Sci 1995; 65: 763-70.

[3] Thind SK, Kapur SP, Sharma JN. Citrus ring spot virus- a new record from Punjab. Plant Dis Res1995; 10: 75-7.

[4] Thind SK, Arora PK. Incidence and Behaviour of Ring spot virus in citrus. Indian J Virol 1997; 13:159-60.

[5] Sharma S, Singh B, Rani G, et al. Indian citrus ringspot virus-A review. In: Setia, RC, Setia N, Nayar HK, Eds. Emerging trends in plant and agriculture research. Punjab Agriculture University, Ludhiana: India 2007; 236-46.
Wallace IH, Drake RJ. Citrange Stunt and Ringspot, two previously un-described viral diseases of citrus. In: proc $4^{\text {th }}$ conf Intern Org Citrus Virol Gainesville 1968; pp. 177-93.

[7] Thind SK, Arora PK, Kaur N. Impact of Citrus ringspot virus on biochemical alterations and fruit yield of kinnow mandarin. Indian J Virol 2005; 16: 17-8.

[8] Sharma S, Singh B, Rani G, et al. Current status of Indian citrus ringspot virus (ICRSV) in kinnow orchards of Punjab and neighbouring states. J Curr Biosci 2004; 2: 132-5.

Timmer LW, Benatena HN. Comparison of psorosis and other viruses causing leaf flecking in citrus. Intern Citrus Cong (2nd: 1977: Orlando, Florida), Intern Soc Citriculture 1977; 3: 930-5.

Derrick KS, Lee RF, Hewitt BG, Barthe GA, Da Graca JV. Characterization of Citrus ringspot virus. In: Brlansky RH, Lee RF, Timmer LW Eds. Proc. $11^{\text {th }}$ Conf. Intern Org Citrus Virol. Riverside, USA 1991; pp. 386-90.

Navas-Castillo J, Moreno P. Biological diversity of citrus ringspot isolates in Spain. Plant Pathol 1993; 42: 347-57.

ringspot and Citus psorosis viruses have particles of novel filaringspot and Citrus psorosis viruses have particles of novel filamentous morphology. J Gen Virol 1994; 75: 3585-90.

[13] Barthe GA, Ceccardi TL, Keremane L, Manjunath L, Derrick KS. Citrus psorosis virus: nucleotide sequencing of the coat protein gene and detection by hybridization and RT-PCR. J Gen Virol 1998; 79: 1531-7.

[14] Torre MES, Lopez C, Grau O, Garcia ML. RNA2 of Citrus Psorosis virus is of negative polarity and has a single open reading frame in its complementary strand. J Gen Virol 2002; 83: 1777-81.

[15] Milne RG, Garcia ML, Grau O. Genus Ophiovirus. Type species Citrus Psorosis virus (CPsV). In: Van Regenmortel MHV, Fauquet CM, Bishop DHL, et al. Eds. Virus Taxonomy, $7^{\text {th }}$ Rep Intern Comm Taxonomy Viruses. Academic Press: USA 2000; 627-31.

[16] Rustici G, Accotto GP, Noris E, Masenga V, Luisoni E, Milne RG. Indian citrus ring spot virus: a proposed new species with some affinities to Potex-, Carla, Fovea- and Allexiviruses. Arch Virol 2000; 145: 1895-908.

[17] Rustici G, Milne RG, Noris E, et al. Further characterization and detection of Indian citrus ringspot virus. Proc $14^{\text {th }}$ Conf Intern Org Citrus Virol Riverside: Brazil 2000; 360-2.

[18] Clark MF, Adams AN. Characteristics of the microplate method of enzyme linked immunosorbent assay for the detection of plant viruses. J Gen Virol 1977; 34: 475-83.

[19] Zaidi AA, Sood A, Mukherjee. Transmission, detection and control of viruses in orchids. J Orchid Soc India 1991; 5: 17-24.

[20] Pant RP, Ahlawat YS. Studies on citrus ring spot in India. In: Proc. Inern. Sym. Citriculture, NRC for Citrus, Nagpur: India 1999; 3857 .

[21] Webster CG, Wylie SJ, Jones MGK. Diognosis of plant viral pathogens. Curr Sci 2004; 86: 1604-07.

[22] Koenig R, Paul HL. Variants of ELISA in plant virus diagnosis. J Virol Methods 1982; 5: 113-25.

[23] Nickel O, Fajardo TV, Trivilin AP, Targon MLNP, Machado MA. Production and use of polyclonal antibodies to the coat protein of Apple stem grooving virus expressed in Escherichia coli. Acta Hort 2004; 657: 35-40.

[24] Kamenova I, Adkins S. Comparison of detection methods for a novel tobamovirus isolated from Florida hibiscus. Plant Dis 2004; 88: 34-40.

[25] Juhasz ACP, Da Silva DJH, Junior FMZ, Soares BO, Aguilera GAH. Screening of Lycopersicon sp. accessions for resistance to Pepper yellow mosaic virus. Sci Agric 2006; 63: 510-12.

[26] Elibuyuk IO. Investigation of Plum pox virus in different tissues of Apricot and plum trees. Plant Pathol J 2006; 5: 208-11.

[27] Matthews DM, Riley K, Dodds JA. Comparison of detection methods for citrus tristeza virus in field trees during months of nonooptimal titer. Plant Dis 1997; 81: 525-9.

[28] Sambade A, Martin S, Olmos A, et al. A fast one step reverse transcription and polymearse chain reaction (RT-PCR) amplification procedure providing highly specific complementary DNA from plant virus RNA. J Virol Methods 2000; 87: 25-8.

[29] Helguera PR, Taborda R, Docampo DM, Ducasse DA. Immunocapture reverse transcription- polymerase chain reaction with nested PCR greatly increases the detection of Prunus necrotic ring spot virus in the peach. J Virol Methods 2001; 95: 93-100.

[30] Ito T, Ieki H, Ozaki K. Simultaneous detection of six citrus viroids and Apple stem grooving virus from citrus plants by multiplex re- 
verse transcription polymerase chain reaction. J Virol Methods 2002; 106: 235-9.

[31] Katoch M, Abdin MZ, Ram R, Zaidi AA. An overview of diagnostics for viruses infecting gladiolus. Crop Prot 2003; 22: 153-6.

[32] Manganaris GA, Economu AS, Boubourakas IN, Katis NI. Elimination of PPV and PNRSV through thermotherapy and meristem tip culture in nectarine. Plant Cell Rep 2003; 22: 195-200.
[33] Ram R, Verma N, Singh AK, Singh I, Hallan V, Zaidi AA. Indexing and production of virus-free chrysanthemums. Biol Plant 2005; 49: $149-52$.

[34] Verma N, Ram R, Zaidi AA. In vitro production of Prunus necrotic ringspot virus-free begonias through chemo-and thermotherapy. Sci Hort 2005; 103: 239-47.

[35] Walsh K, North J, Barker I, Boonham N. Detection of different strains of Potato virus $Y$ and their mixed infections using competitive fluorescent RT-PCR. J Virol Methods 2001; 91: 167-73.

Received: November 11, 2008

Revised: December 12,2008

Accepted: January 27, 2009

(C) Sharma et al.; Licensee Bentham Open.

This is an open access article licensed under the terms of the Creative Commons Attribution Non-Commercial License (http://creativecommons.org/licenses/by$\mathrm{nc} / 3.0 /$ ), which permits unrestricted, non-commercial use, distribution and reproduction in any medium, provided the work is properly cited. 